Archives of Agriculture and Environmental Science

\title{
Current status of bacterial wilt (Ralstonia solanacearum) disease in major tomato (Solanum lycopersicum L.) growing areas in Egypt
}

\author{
Sameh Elnaggar, Atef M. Mohamed* (iD , Abderadi Bakeer and Toba A. Osman \\ Department of Botany, Faculty of Agriculture, Fayoum University, 63514-Fayoum, EGYPT \\ *Corresponding author's E-mail: amm12@fayoum.edu.eg
}

\section{ARTICLE HISTORY}

Received: 19 November 2018

Revised received: 26 November 2018

Accepted: 30 November 2018

\section{Keywords}

Incidence

Polymerase chain reaction

Ralstonia

Severity

Tomato

\section{ABSTRACT}

A survey was carried out to determine the current status of bacterial wilt (Ralstonia solanacearum) disease in major tomato growing areas in Egypt incidence and distribution. In the 2014/2015 cropping season in major tomato growing areas of Upper and Lower Egypt. In upper highest incidence of bacterial wilt occurred in Luxour Governorate (10.29\%) and lowest in Al- Giza Governorate (9.41\%). Wilt severity was recorded (3.44\%) in Luxour Governorate and the lowest (2.60\%) was recorded in Sohag Governorate. In Lower Egypt Governorates, the highest disease incidence was recorded in Al- Behiera (15.28\%) followed by Al-Daqahlia, (13.23), Al- Gharbia (12.41), Kafr Al-Shikh(12.70) and Al- Sharqia (12.14) Governorates. The lowest disease incidence recorded in Al- Suiz Governorate (10.27\%), followed by $11.28,11.58$ and $11.67 \%$ in Al- Qalioubia, Al- Ismailia and Al- Minoufia Governorates respectively. The highest bacterial wilt severity was recorded in Al- Behiera Governorate, fields (5.70\%), followed by Al- Gharbia (4.60\%), while the lowest bacterial wilt severity was recorded in Al- Suiz Governorate (2.63\%), followed by 3.30, in Al- Qalioubia Governorate. All the collected plants were subjected to PCR to detect the infected samples. The expected $288 \mathrm{bp}$ amplicon was detected in bacterial wilt infected samples from above mentioned governorates and diseases percentage and severity were calculated.

(C)2018 Agriculture and Environmental Science Academy

Citation of this article: Elnaggar, S., Mohamed, A.M., Bakeer, A. and Osman, T.A. (2018). Current status of bacterial wilt (Ralstonia solanacearum) disease in major tomato (Solanum lycopersicum L.) growing areas in Egypt. . Archives of Agriculture and Environmental Science, 3(4): 399-406, https://dx.doi.org/10.26832/24566632.2018.0304012

\section{INTRODUCTION}

Tomato (Solanum lycopersicum L.), is an economically important crop which belongs to the Family Solanaceae. Leading tomato producing countries include China, USA, India, Turkey, Egypt, Italy, Iran, Spain, Brazil, and Mexico (Desneux et al., 2011). Bacterial wilt of tomato caused by $R$. solanacearum, causes a considerable amount of damage to tomatoes and many other crops in tropical, subtropical and warm temperature regions of the world and limits the produc-tion of many crops e.g. potato, tomato, eggplant and pepper (Williamson et al., 2002; Ji et al., 2005). Ralstonia solanacearum, is widespread in tropical and subtropical regions. Its harmfulness, wide host range, persistence and huge genome plasticity have made it one of the world's most important phytopathogenic bacteria and one of the most inten- sively studied. Bacterial wilt caused by $R$. solanacearum is one of the major diseases of tomato and the disease causes concern for tomato production because it can drastically reduce tomato up to $90 \%$. Bacterial wilt, caused by members of the Ralstonia solanacearum species complex, is a key emergent disease in non-tropical regions of the world. It can infect over 200 plant species representing over 50 botanical families (Abo-Elyousr and Asran, 2009; Milling et al., 2011; Fujiwara et al., 2012; Aslam et al., 2017). Kim et al. (2016) reported that, Bacterial wilt of tomatoes caused by $R$. solanacearum is a devastating disease that limits the production of tomato in Korea. R. solanacearum, the causal agent of bacterial wilt disease, is considered one of the most destructive bacterial pathogens due to its lethality, unusually wide host range, persistence and broad geographical distribution Wei et al. (2018). 
The objective of this survey, therefore, was to determine the current distribution and relative importance of bacterial wilt of tomato in Egypt.

\section{MATERIALS AND METHODS}

\section{Surveying and sampling}

A survey was carried out to know the status of bacterial wilt of tomato in Egypt in terms of its incidence and severity in seventeen governorates viz. Al- Giza, Al- Fayoum, Beni Seuief, Al- Minia, Assiut, Sohag, Qena, Luxor, Al- Qalioubia, Al- Minoufia, Al- Gharbia, Al- Daqahlia, Kafr Al- Shikh, Al- Sharqia, Al- Ismailia, Al- Suiz and Al- Behiera. Field surveys were conducted in the third to fourth week of March 2014/2015 and the last week of November to second week of December in 2015/2016 cropping seasons. At least three counties in each governorate and three to five locations in each counties and three to five farmer's fields from each location were surveyed to record the bacterial wilt incidence and severity. The plants were inspected at the nursery stage, after transplanting, at flowering stage and at the fruiting stage. The total number of healthy and wilted plants was counted in a $1 \mathrm{~m}^{2}$ area and percentage wilt incidence was recorded. Information on the cultivars grown in the area and related field history was gathered from the farmers.

\section{Field symptomology}

For proper key diagnostic identification of R. solanacearum in the field and to distinguish bacterial wilt from vascular wilts caused by fungal pathogens, bacterial wilt symptoms was identified by visual observation of typical bacterial wilt disease symptoms such as wilting, vascular discoloration, bacterial streaming in glass of water and browning of the vascular bundles of the tuber. Milky white strands containing bacteria and extracellular polysaccharide was oozed out from the cut ends of the xylem.

\section{Disease samples}

The plant and soil samples from wilt affected tomato and potato plants showing typical symptoms of bacterial wilt were collected from farmer's field. At least 10 samples of the diseased plants were collected from each of the surveyed district. The diseased samples were brought to the laboratory and subjected aseptically for detection and confirmation of Ralstonia solanacearum.

\section{Assessment of disease incidence and severity}

The status of bacterial wilt of tomato and potato was surveyed in terms of its incidence and severity. Data on wilt incidence were recorded in at least three locations from three to five farmer's fields for each district. Then the per cent wilt incidence was calculated by the following formula:

$$
\% \text { Wilt incidence }=\frac{\text { Number of wilted plants in each field }}{\text { Total number of plants in each field }} \times 100
$$

Ten plants were randomly selected from each farmer field from each location to calculate the wilt severity in each district. The severity of bacterial wilt was recorded based on the severity scale as described previously by Horita and Tsuchiya (2001), briefly,

1= No symptom, 2 = Top young leaves wilted, 3 = Two leaves wilted, 4 =Four or more leaves wilted and $5=$ Plant dies.

\section{Disease severity index (DSI\%) $=\Sigma(\mathrm{pn}) 100 / \mathrm{PN}$}

\section{Where's}

$\mathrm{p}=$ disease severity grade, $\mathrm{n}=$ number of plants at the grade, $\mathrm{P}=$ the highest disease severity grade, $N=$ number of total test plants.

PCR detection and confirmation of Ralstonia solanacearu DNA extraction

DNA was extracted from infected tomato plants using DNeasy plant kit (QIAGEN) following the manufacturer's manual. The DNA concentration was estimated using a biophotometer (Eppendorf), by measuring the absorbance at $260 \mathrm{~nm}$, and adjusted to $25 \mathrm{ng} \mu \mathrm{L}^{-1}$. DNA was stored at $-20^{\circ} \mathrm{C}$. DNA from healthy plants was used as positive control.

\section{PCR detection and confirmation of $R$. solanacearum}

The samples were detected by using $R$. solanacearum species complex-specific primer pairs 759/760 (10 $\mu \mathrm{M}$ each per reaction; Opina et al. (1997). PCR was set up in a total $25 \mu \mathrm{L}$ reaction comprising $25 \mu \mathrm{L}$ of Fermentas $2 X$ PCR enzyme mix (Thermofisher Scientific), $5 \mu \mathrm{L}$ of $\mathrm{Q}$ solution (5X QIAGEN) and 25 ng gDNA on a (BIO-RAD) thermal cycler (C1000) with the following cycling conditions: initial denaturation for $5 \mathrm{~min}$ at 95 ${ }^{\circ} \mathrm{C}$; 30 cycles of $30 \mathrm{~s}$ at $94^{\circ} \mathrm{C}, 1 \mathrm{~min}$ at $59^{\circ} \mathrm{C}$ and $1 \mathrm{~min}$ at $72^{\circ} \mathrm{C}$; and final extension of $10 \mathrm{~min}$ at $72{ }^{\circ} \mathrm{C}$. The expected $288-\mathrm{bp}$ reference PCR products from the ribosomal DNA specific of Ralstonia solanacearum species were revealed by electrophoresis through $1.5 \%$ agarose gel in 50X TAE (Tris-acetate-EDTA) buffer stained with ethidium bromide and gels were imaged in GeneSnap (a Syngene Bioimaging System, Syngene) with UV transilluminator at a wavelength of $302 \mathrm{~nm}$ and compared with a $1 \mathrm{~Kb}$ Plus marker ladder. A positive identification was based on the presence of a $288 \mathrm{bp}$ amplicon.

\section{RESULTS AND DISCUSSION}

Incidence and severity of bacterial wilt a total of selected governorates

Tomato (Solanum lycopersicum L.) is one of the most important vegetable crops in Egypt. Soil borne diseases including bacterial wilt caused a considerable loss in quantity and quality of tomato yield. An extensive survey was conducted throughout eight hundred ten fields at thirty two Counties of eight governorates. The results of survived tomato cultivars grown under tested fields at all Counties for the percentage of bacterial wilt disease incidence and percentage of disease 
severity are shown in Table $(1,2)$. The percentage of disease incidence and disease severity were calculated during 20142015, transplanting season. Our results revealed that tomato cultivars grown under open field conditions are susceptible to different degrees, disease infection with soil borne diseases. Bacterial wilt disease was distributed over the entire tested tomato field where over all averages of disease incidence and disease severity were 9.88 and $3.01 \%$, in Upper Egypt governorates while in Low Egypt governorates were 12.30 and 4.02\%, respectively. Bacterial wilt disease of tomato was found in all districts surveyed but not in all fields (Table 1,2). Common bacterial wilt symptoms observed in the fields were wilting of one side of a leaf and/ or stem, general whole plant wilting and brown discoloration of the vascular system in young stems (Figure $1 \mathrm{a}-\mathrm{c}$ ). Wilting was the most obvious systemic symptom in the field. In Upper Egypt Governorates, Luxour Governorate tested fields recorded the highest percentage of bacterial wilt disease being 10.29 followed by Assuit and Al- Minia Governorates 10.21 and 10.10\% respectively, while Al- Giza Governorate tested field recorded the lowest significantly percentage of disease incidence being $9.41 \%$ followed by Sohag and Al- Fayoum Governorates 9.59 and $9.69 \%$. On the contrary, the highest bacterial wilt severity was recorded in Luxour Governorate (3.44\%), followed by Assuit and Al- Minia Governorates which were 3.17 and $3.13 \%$ respectively, while Sohag Governorate tested field recorded the lowest significantly percentage of disease severity $2.60 \%$ followed by Al- Giza and Al- Fayoum Governorates 2.69 and $2.85 \%$, comparing with the other tested fields.

Table 1. Survey of tomato bacterial wilt disease incidence under Giza governorate conditions during 2014-2015 growing season.

\begin{tabular}{|c|c|c|c|}
\hline \multirow{2}{*}{ Governorate } & \multirow{2}{*}{ County } & \multicolumn{2}{|c|}{ Infection (\%) } \\
\hline & & Disease incidence & Disease severity \\
\hline \multirow{4}{*}{ Giza } & Atfeeh & 10.03 & 2.90 \\
\hline & Al-Saff & 8.80 & 2.45 \\
\hline & Al- Ayatt & 9.27 & 2.54 \\
\hline & Al- Bdrasheen & 9.56 & 2.87 \\
\hline \multirow[t]{3}{*}{ Average } & & 9.41 & 2.69 \\
\hline & Tamya & 10.04 & 2.86 \\
\hline & Sennoures & 9.44 & 2.79 \\
\hline \multirow{4}{*}{ Al- Fayoum } & Abshway & 9.22 & 2.69 \\
\hline & Itsa & 11.10 & 3.50 \\
\hline & Yousef Al-Sediq & 10.97 & 3.33 \\
\hline & Al-Fayoum & 7.40 & 1.90 \\
\hline \multirow[t]{3}{*}{ Average } & & 9.69 & 2.85 \\
\hline & Ehnasia & 9.56 & 2.96 \\
\hline & Al-Fashn & 11.57 & 4.05 \\
\hline \multirow[t]{3}{*}{ Beni Sueif } & Al-Wasta & 9.82 & 3.04 \\
\hline & Nasser & 9.07 & 2.38 \\
\hline & Beni Sueif & 9.72 & 2.97 \\
\hline \multirow{2}{*}{ Average } & & 9.95 & 3.08 \\
\hline & Matai & 9.98 & 2.88 \\
\hline \multirow{3}{*}{ Al-Minia } & Samalout & 9.30 & 2.78 \\
\hline & Al- Minia & 10.53 & 3.42 \\
\hline & Al- Edwa & 10.58 & 3.43 \\
\hline \multirow[t]{2}{*}{ Average } & & 10.10 & 3.13 \\
\hline & Al-Qousia & 9.56 & 2.83 \\
\hline \multirow[t]{2}{*}{ Assuit } & Dayrout & 10.52 & 3.31 \\
\hline & Assuit & 10.55 & 3.37 \\
\hline \multirow[t]{2}{*}{ Average } & & 10.21 & 3.17 \\
\hline & Akhmim & 10.05 & 2.83 \\
\hline \multirow{3}{*}{ Sohag } & Gerga & 9.20 & 2.41 \\
\hline & Dar Al-Salam & 9.62 & 2.63 \\
\hline & Tahta & 9.49 & 2.54 \\
\hline \multirow[t]{2}{*}{ Average } & & 9.59 & 2.60 \\
\hline & Qena & 9.14 & 2.46 \\
\hline \multirow{3}{*}{ Qena } & Al- Waqf & 9.28 & 3.09 \\
\hline & Qous & 10.03 & 3.34 \\
\hline & Qeft & 10.67 & 3.45 \\
\hline \multirow[t]{3}{*}{ Average } & & 9.78 & 3.09 \\
\hline & Asfoun & 9.22 & 3.11 \\
\hline & Al-Deer & 8.55 & 2.56 \\
\hline \multirow[t]{3}{*}{ Luxor } & Al- Nemsa & 12.70 & 4.11 \\
\hline & Isna & 10.67 & 3.77 \\
\hline & Al- Ngoaa Qebly & 10.33 & 3.66 \\
\hline Average & & 10.29 & 3.44 \\
\hline General average & & 9.88 & 3.01 \\
\hline
\end{tabular}



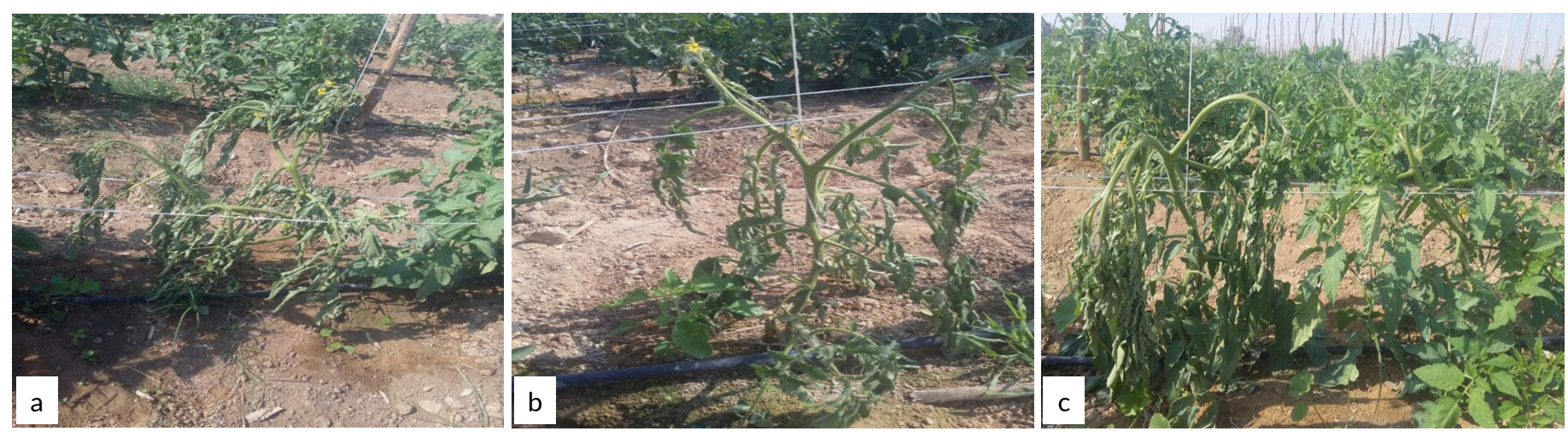

Figure 1 (a-c). Naturally infected tomato plants showing bacterial wilt symptoms.

Table 2. Survey of tomato bacterial wilt disease incidence under Low Egypt Governorate conditions during 2014-2015 growing season.

\begin{tabular}{|c|c|c|c|}
\hline \multirow{2}{*}{ Governorate } & \multirow{2}{*}{ County } & \multicolumn{2}{|c|}{ Infection (\%) } \\
\hline & & Disease incidence & Disease severity \\
\hline \multirow{3}{*}{ Al-Qalioubia } & Banha & 10.97 & 2.93 \\
\hline & Toukh & 11.55 & 3.53 \\
\hline & Qalioub & 11.32 & 3.44 \\
\hline \multirow[t]{3}{*}{ Average } & & 11.28 & 3.30 \\
\hline & Ashmoun & 10.71 & 2.72 \\
\hline & Albagour & 10.86 & 2.76 \\
\hline \multirow[t]{3}{*}{ Al-Minoufia } & Quesna & 11.68 & 3.81 \\
\hline & Minouf & 11.27 & 3.46 \\
\hline & Al-Shouhadaa & 13.84 & 4.27 \\
\hline \multirow[t]{3}{*}{ Average } & & 11.67 & 3.40 \\
\hline & Tanta & 13.05 & 4.71 \\
\hline & Qtour & 12.64 & 4.34 \\
\hline \multirow[t]{3}{*}{ Al-Gharbia } & Kafr Al- Zayat & 14.44 & 4.96 \\
\hline & Santah & 13.18 & 4.71 \\
\hline & Zefta & 12.41 & 4.29 \\
\hline \multirow[t]{3}{*}{ Average } & & 13.14 & 4.60 \\
\hline & Belkas & 12.57 & 4.18 \\
\hline & Dkerns & 11.94 & 4.04 \\
\hline \multirow{4}{*}{ Al-Daqahlia } & Al-Mansoura & 13.84 & 4.88 \\
\hline & Meet Ghamr & 13.94 & 4.98 \\
\hline & Sherbin & 13.12 & 4.47 \\
\hline & Talkha & 13.96 & 4.99 \\
\hline \multirow[t]{2}{*}{ Average } & & 13.23 & 4.59 \\
\hline & Al-Ryad & 11.31 & 3.82 \\
\hline \multirow[t]{2}{*}{ Kafr Al- Sheikh } & Qeleen & 12.44 & 4.40 \\
\hline & Biala & 12.70 & 4.42 \\
\hline \multirow[t]{2}{*}{ Average } & & 12.15 & 4.21 \\
\hline & Belbis & 12.84 & 4.38 \\
\hline \multirow{3}{*}{ Al-Sharqia } & Al-Housainiah & 11.49 & 3.64 \\
\hline & Faqous & 12.67 & 4.03 \\
\hline & Abou-Hammad & 11.55 & 3.67 \\
\hline \multirow[t]{3}{*}{ Average } & & 12.14 & 3.93 \\
\hline & Al-Qsasin & 11.33 & 3.67 \\
\hline & Al-Salhia & 11.52 & 3.84 \\
\hline \multirow{4}{*}{ Al- Ismailia } & Aou Ashour & 11.83 & 3.89 \\
\hline & Al-Zaheria & 12.56 & 4.38 \\
\hline & Al- Qarin & 11.89 & 3.97 \\
\hline & Kafr Al -Shiekh Attia & 10.33 & 3.32 \\
\hline \multirow[t]{2}{*}{ Average } & & 11.58 & 3.85 \\
\hline & Kafr Alnaggar & 10.67 & 2.83 \\
\hline \multirow{3}{*}{ Al-Suiz } & Kafr Al- Arab & 9.40 & 2.78 \\
\hline & Genifa & 10.54 & 2.56 \\
\hline & Kabreet & 10.45 & 2.34 \\
\hline \multirow[t]{4}{*}{ Average } & & 10.27 & 2.63 \\
\hline & Hosh Eisa & 14.66 & 4.65 \\
\hline & Al- Noubaria & 15.25 & 5.33 \\
\hline & Wadi Al-Natroun & 16.33 & 7.76 \\
\hline \multirow[t]{4}{*}{ Al-Behiera } & Al-Mahmoudia & 14.73 & 4.88 \\
\hline & Abou Amtamir & 15.50 & 5.67 \\
\hline & Saft Al- Houria & 16.30 & 6.75 \\
\hline & Al-Tawfikia & 14.22 & 4.87 \\
\hline Average & & 15.28 & 5.70 \\
\hline General Average & & 12.30 & 4.02 \\
\hline
\end{tabular}


The results presented in Table (1) indicate that the highest average of bacterial wilt disease incidence was recorded in Al- Nemsa County (Luxour Governorate) $12.70 \%$, followed by Al - Fashn (Beni Sueif Governorate) 11.57\%and Itsa county (Al- Fayoum Governorate )11.10\% while the lowest bacterial wilt incidence (8.55\%) was recorded in Al- Deer (Luxour Governorate) followed by 8.80 and $9.07 \%$ in Al- Saff and Nasser Counties (Al- Giza and Beni Sueif Governorates) (Table 1). Moreover, $10.67 \%$ bacterial wilt disease incidence was recorded in Qeft and Isna (Qwna and Luxour Governorates).

In Al- Nemsa County (Luxour Governorate) fields a higher disease severity was observed than all areas $4.11 \%$, followed by Al- Fashn, Isna and Al- Ngoaa Qebly (Beni Sueif and Luxour Governorates) $4.05,3.77$ and $3.66 \%$, while the lowest severity recorded in Al- Fayoum, Nsser and Gerga Counties Which were 1.90, 2.38 and $2.41 \%$ respectively. (Table 1 ). Moreover, these variations of wilt incidence and severity may be attributed due to the diversity of $R$. solanacearum isolates and also due to the variations in soil factors prevailing in different locations surveyed. A noteworthy, all tested field in Lower Egypt Governorates was found to be attacked by bacterial wilt pathogen. The results in Table (2) clearly demonstrated that, the surveyed plants at early stages (3-6 weeks after transplanting) showed root infections expressed at highest records with bacterial wilt infection. The infection gradually increased in severity reaching the highest level at 8-12 weeks. Also, all the surveyed of tomato cultivars under open field were susceptible to bacterial wilt. In Al- Behiera Governorate, fields rcorded a higher disease incidence and severity than all Governorates, the highest disease incidence were $15.28 \%$ followed by Al-Daqahlia, Al- Gharbia, Kafr Al- Shikh and Al- Sharqia Governorates which were $13.23,13.14,12.15$ and $12.14 \%$ respectively, besides, the lowest disease incidence recorded in Al- Suiz Governorate (10.27\%), followed by $11.28,11.58$ and $11.67 \%$ in Al- Qalioubia, Al- Ismailia and Al- Minoufia Governorates respectively. On the other hand, the highest bacterial wilt severity was recorded in Al- Bhira Governorate, fields (5.70\%), followed by Al- Gharbia (4.60\%), Al-Daqahlia, (4.59\%) and Kafr Al- Shiekh , (4.21\%). while the lowest bacterial wilt severity was recorded in Al- Suiz
Governorate (2.63\%), followed by 3.30, 3.40, 3.85 and $3.93 \%$ in Al- Qalioubia, Al- Minoufia, Al- Ismailia and Al- Sharqia Governorates respectively. Data also showed that the highest disease infection percentage on tomato were $16.33 \%$ in Wadi Al-Natroun County fields followed by Saft Al- Houria, Abou Al-Mtamier Al- Noubaria, Al- Mahmoudia, Housh Eisa, AlTawfikia and Kafr Al- Zayat counties which were (16.30, $15.50,15.25$ and $14.73,14.66,14.44 \%)$, followed by (13.96 and 13.94\%) in Talkha and Meet Ghamr respectively. While, Al- Shouhadaa and Al- Mansoura counties recorded the same disease incidence (13.84 \%), followed by (13.18\%), in Santah, (13.12\%) in Sherbien and (13.05\%), in Tanta counties. In Kafr Al- Sheikh Attia, Kabreet and Genifacounties recorded the lowest disease incidence (10.33, 10.45 and 10.54\%) respectively, followed by Ashmoun, Al- Bagour and Banha (10.71, 10.86 and $10.97 \%$ ), respectively. On the contrary, the highest bacterial wilt severity was recorded in Wadi El- Natroun, Saft Al- Houria, Abou Al- Mtamier and Al- Noubaria (7.76, 6.75, 5.67 and $5.33 \%$ ) respectively, followed by $4.99,4.98,4.96 \%$ in Talkha, Meet Ghamr and Kafr Al- Zayat respectively, in addition Al- Mansoura and Al- Mahmoudia recorded the same severity $4.88 \%$. while the lowest severity recorded in Kabreet, Ganifa, Ashmoun and Albagour (2.34, 2.56, 2,72 and 2.76\%), respectively. During survey it was noticed that, a higher disease incidence was found in old fields compared to new fields. Most farmers did not practice crop rotation and often plant seedling from their own nurseries which was found to increase disease incidences. Poor agronomic practices such as farmers may not scout fields, poor field sanitation and flood irrigation were identified as key factors to spread the disease to new fields. The variation between the disease incidence and severity at all the tested fields probably due to one or more of the following factors, their plantation in heavily infested soil or overwatering or poor drainage; overcrowding or poor ventilation of seedlings and excess application of nitrogen; or existing of pathogenic nematodes are present. Interestingly, this investigation on those tested tomato cultivars in all Governorates was unprecedented and the results obtained could fill a gap in such research domain for more investigations in the near and immediate future.

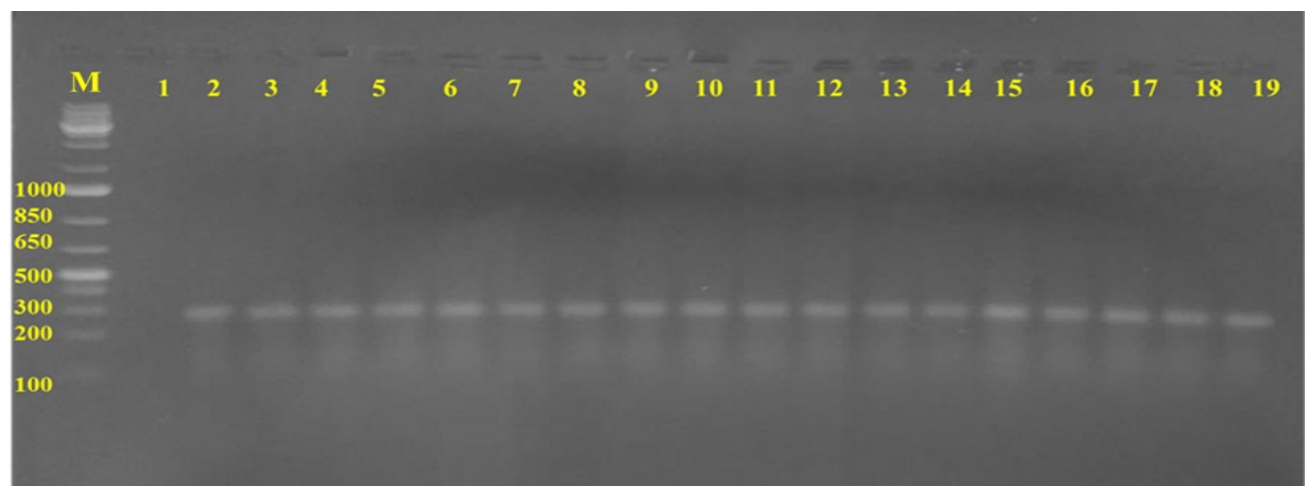

Figure 2 (a). Single DNA band in the tested plants and the positive control one with very close similarity among them at MW $288 \mathrm{bp}$.

Lane 1= Negative control (Healthy plant), 2 = positive control (reference isolate of $R$. solanacearum identified by the Brown Rot Project, Egypt), lanes, $3=$ samples of Atfeeh, 4 = samples of Al- Ayatt, $5=$ samples of Al-Saff, $6=$ samples of Al-Badrshein, $7=$ samples of Tmya, $8=$ samples of Senoures $9=$ samples of Abshoway, 10= samples of Itsa, 11=samples of Youssef Alsedia, 12= samples of Al- Fayoum, 13= samples of Ehnasia, 13= samples of Al- Fashn, 14= samples of Al- Wasta, 15= samples of Nasser, 16= samples of Beni Suief, 17= samples of Matai, 18= samples of Samalout, 19= samples of Al- Minia. 


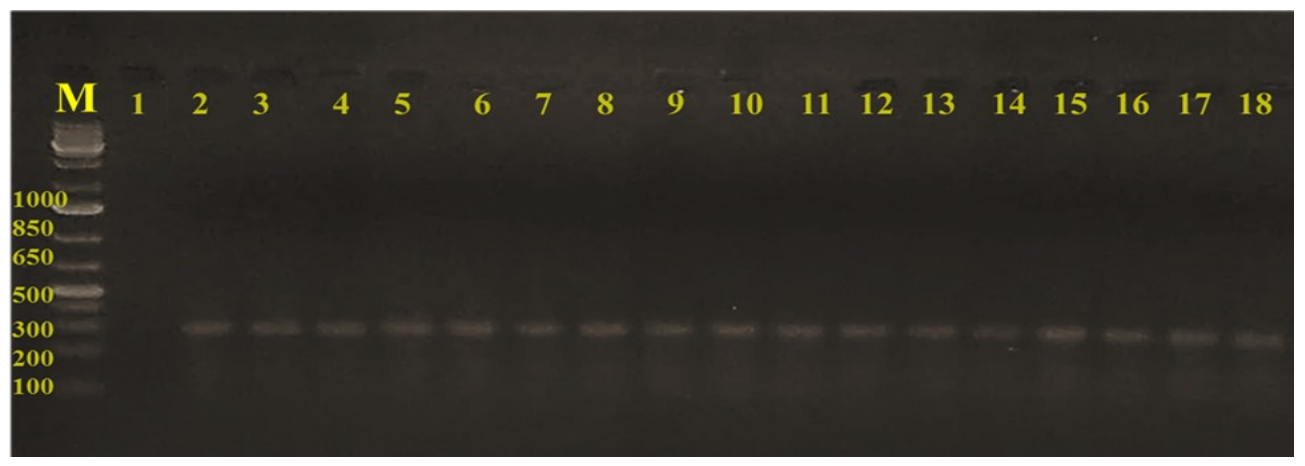

Figure 2 (b). Single DNA band in the tested plants and the positive control one with very close similarity among them at MW $288 \mathrm{bp}$.

Lane 1= Negative control (Healthy plant), 2 = positive control (reference isolate of $R$. solanacearum identified by the Brown Rot Project, Egypt), lanes, $3=$ samples of Al-Edwa, $4=$ samples of Al- Qousia, 5= samples of Dayrout, 6= samples of Assuit, 7= samples of Akhmim, 8= samples of Gerga 9= samples of Dar Al- Salam, 10= samples of Tahta, 11=samples of Qena, 12= samples of Al-Wagf, 13= samples of Qous, 13= samples of Qeft, 14= samples of Asfoun, 15= samples of Al- Deer, 16= samples of Al- Nemsa, 17= samples of Isna, 18= samples of Al- Ngouaa Qebly.

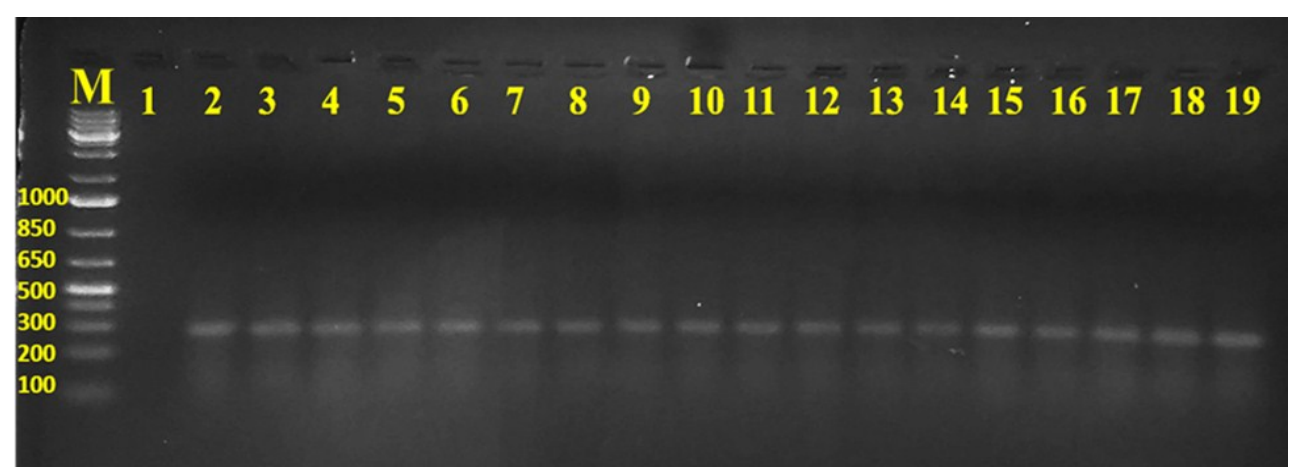

Figure 2 (c). Single DNA band in the tested plants and the positive control one with very close similarity among them at MW $288 \mathrm{bp}$.

Lane 1= Negative control (Healthy plant), 2 = positive control (reference isolate of R. solanacearum identified by the Brown Rot Project, Egypt), lanes, $3=$ samples of Banha, 4 = samples of Toukh, 5= samples of Qalioub, 6= samples of Ashmoun, 7= samples of Albagour, 8= samples of Quesna 9= samples of Minouf, 10 = samples of Al-Shohadaa, 11=samples of Tanta, 12= samples of Qotour, 13= samples of Kafr Al-Zayat, 13= samples of Santah, 14= samples of Zefta, 15= samples of Belkas, 16= samples of Dekernes, 17= samples of Al- Mansoura, 18= samples of Meet Ghamr. 19= samples of Sherbin.

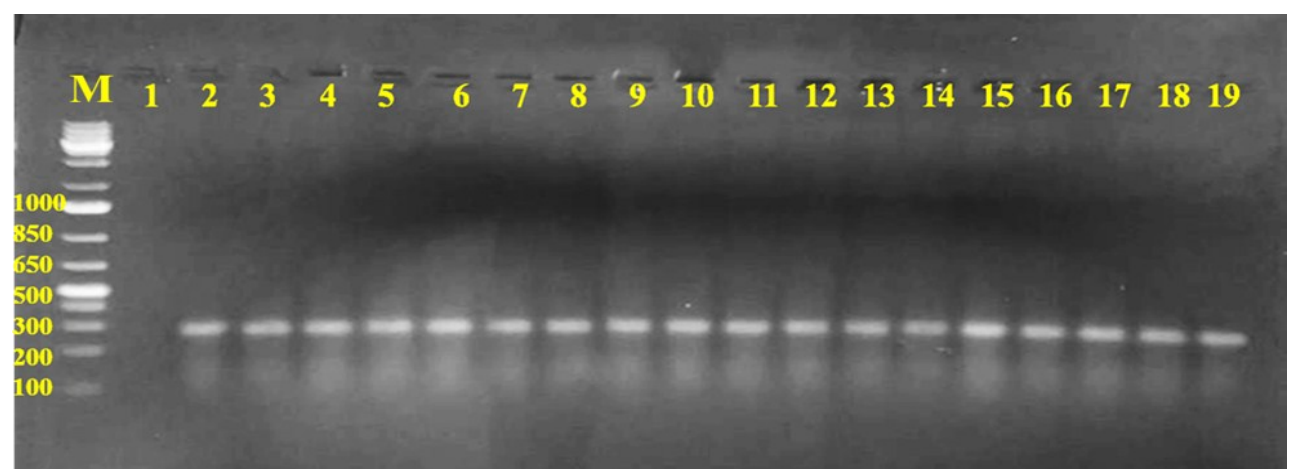

Figure 2 (d). Single DNA band in the tested plants and the positive control one with very close similarity among them at MW $288 \mathrm{bp}$.

Lane 1= Negative control (Healthy plant), 2 = positive control (reference isolate of R. solanacearum identified by the Brown Rot Project, Egypt), lanes, $3=$ samples of Talkha, $4=$ samples of Al- Ryad, 5= samples of Qeleen, 6= samples of Biala, 7= samples of Belbis, 8= samples of Al- Housainiah, $9=$ samples of Faqous, 10 = samples of Abou- Hammad, 11=samples ofAl- Qsasien, 12= samples of Al-Zaheria, 13= samples of Al- Salhia, 13= samples of Abou Ashour, 14= samples of Al- Qarien, 15= samples of Kafr Al-Shiekh Attia, 16= samples of Kafr Al- Naggar, 17= samples of Kafr Al-Arab, 18= samples of Genifa, 19= samples of Kabreet.

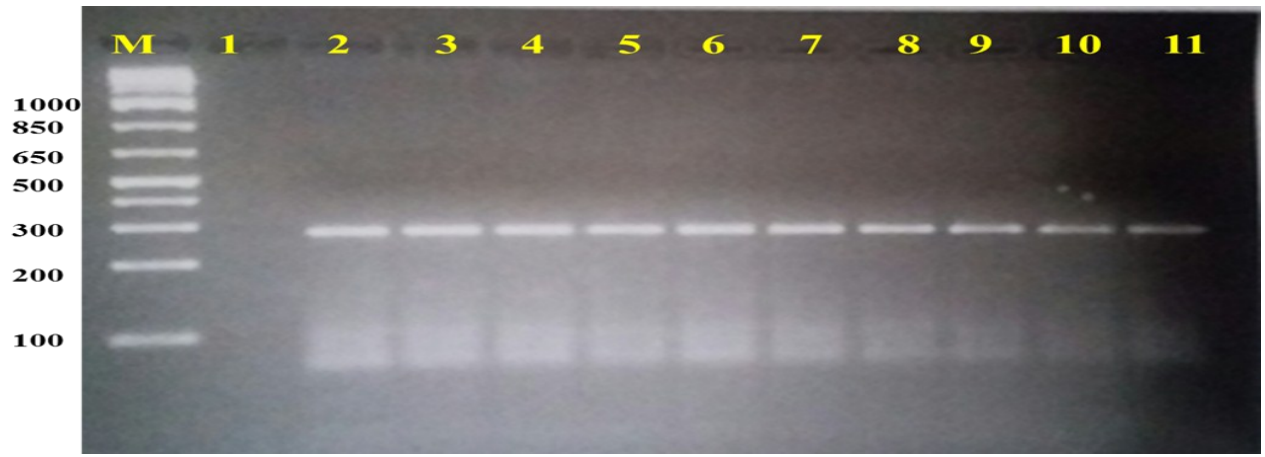

Figure 2 (e). Single DNA band in the tested plants and the positive control one with very close similarity among them at MW $288 \mathrm{bp}$.

Lane 1= Negative control (Healthy plant), 2 = positive control (reference isolate of $R$. solanacearum identified by the Brown Rot Project, Egypt), lanes, $3=$ samples of Housh Eiesa, 4 = samples of Al- Noubaria, 5= samples of Al- Mahmoudia, 6= samples of Abou Al- Mtamier, 7= samples of Saft Al- Houria, 8= samples of Al- Tawfikia, 9= samples of Saft Al- Houria, 10= samples of Abou-Al-Mtamier, 11=samples of Housh Eiesa, 12= samples of Al- Noubaria. 
PCR detection and confirmation of $R$. solanacearum

Data in Fig. (2 a, b, c, d, and e) confirmed the infection of bacterial wilt pathogen among the infected plants collected from above mentioned governorates (Table 1, 2) during season 2014/2015 which identified as $R$. solanacearum using PCR technique using two oligonucleotide $R$. solanacearum - specific primers $759 / 760$ (5' GTC GCC GTC AAC TCA CTT TCC 3' and 5' GTC GCC GTC AGC AAT GCG GAA TCG 3') visualized the specific DNA band with molecular weight $288 \mathrm{bp}$ in the tested samples and the positive control. The results revealed that PCR of all plants tested were clearly identical to the positive control ( $R$. solanacearum identified by Brown Rot Project in Egypt). These results are in harmony with the obtained results of Pastrik et al. (2002) who reported that PCR is one of the rapid, highly specific and sensitive tests used for detection and identification of $R$. solunacaarum from different sources.

All over the world the disease is very common in tropical regions during warm and humid weather conditions (Temperature range mostly $25-35^{\circ} \mathrm{C}$ ). In Egypt the favorable condition for this disease prevails during monsoon season (July-August when ideal conditions of high humidity and temperature prevail and the crops approach to harvesting time). The data presented in this study substantiate the findings that, the disease is well established in various solanaceous crops grown in variety of vegetable growing areas of the country. Bacterial wilt disease was first observed to cause considerable losses in some fields of the main production areas (Kafr Eddoar and Bosaly in Behara and Etfeeh in Giza) during the 1998-1999 growing season. Disease incidence ranged from 5 to $20 \%$ with obvious symptoms of wilt appeared at $6 \pm 8$ weeks after transplantation. Aly and Abd El Ghafar (2000). Abd-Alla and bashandy, (2008) mentioned that, In Egypt, this disease was first identified in tomato in 2008. The infection symptoms on tomato plants were established at this age, showing stunted growth or completely wilting, resulting in poor fruit quality such as small fruit size and significant yield loss of about $10 \%$. These results are in harmony with those reported by many researchers Singh et al. (2010) who conducted a survey to study the status of bacterial wilt of solanaceous crops caused by R. solanacearum in Northern and Eastern states of India such as Jammu \& Kashmir, Himachal Pradesh, Uttrakhand, Jharkhand and West Bengal. They observed that bacterial wilt disease incidence in tomato and chilli was quite low ( 1 to $3 \%$ ) during summer season, whereas in rainy season, it was ( 4 to $60 \%$ ) in tomato and (3 to $40 \%$ ) in brinjal. Disease incidence in tomato crop was higher compared to other solanaceous crops like brinjal, chilli, capsicum, and potato. Also, Mondal (2011) found that, tomato, brinjal and potato were affected by the disease in west Bengal and percentages of damage were 9.86 to $86.45 \%$, to 10.54 to $85.63 \%$ and 10.72 to $73.82 \%$ respectively. Moreover, Begum et al. (2012) found that, bacterial wilt (BW) caused by $R$. solanacearum in different vegetable growing areas of Pakistan (during AprilSeptember 2008-09) revealed that sweet pepper was highly susceptible with overall incidence percentage of $21.9 \%$ followed by hot pepper (16.6\%), tomato $(13.3 \%)$, potato $(10.5 \%)$ and brinjal (5.5\%). Aggregate incidence in the whole country was 13.8\%. Also, Assefa et al. (2015) reported that, in Ethiopia percentage wilt incidence of bacterial wilt was as high as $63 \%$ on potato, $55 \%$ on tomato and $100 \%$ on pepper. Also, Kago et al. (2016) carried out a survey of bacterial diseases of 10 farms of Potato, tomato and capsicum. A survey was conducted in the period of short rains (October December) in year 2015, covering Kenyan highlands and lowland regions of Nyeri, Kiambu, Nyahururu, Kirinyaga, Murang'a, and Embu counties; the major production zones of potato, tomato and capsicum to determine the prevalence, effects and management measures in practice by farmers in control of $R$. solanacearum. In the survey, farms (75 $\%$ ) in highlands and $25 \%$ in lowlands had plants with symptoms characteristic of bacterial wilt disease. Bacterial wilt incidences in the survey farms were high in Kirinyanga (26.00\%), Murang'a (24.50\%), Nakuru (19.00\%) and Nyandarua (16.04\%); they were low in Nyeri (10.60\%) and Embu (13.05\%) counties. The survey indicated bacterial wilt as a serious challenge in production of Solanaceae crops in central Kenya. Seleim et al. (2014) isolated fifteen Ralstonia solanacearum isolates from thirty-three of infected tomato tissues, water and soil samples which were collected from different localities of Al- Minia, As-siut and Sohag governorates, showning bacterial wilt symptoms or taken from location hit by the disease. Regardless of the differences in soil types and cropping patterns, the bacterial wilt disease was prevalent in all the surveyed areas. Moreover Gutarra et al. (2017) reported that, the current bacterial wilt infestation was investigated by collecting stem samples from wilted plants and detecting Ralstonia solanacearum in total 39 farmers' fields located in the central and northern Peru. R. solanacearum was detected in 19 fields, and in 153 out of the 358 samples analyzed, where $43 \%$ were found to contain $R$. solanacearum.

\section{Conclusion}

The present study was an effort to find out the occurrence of the bacterial wilt disease in major growing tomato areas in Egypt. In Upper Egypt, we found that, the highest disease incidence was recorded in Luxour Governorate (10.29\%) and lowest in Al- Giza Governorate (9.41\%). The wilt severity was recorded highest level (3.44\%) in Luxour Governorate and the lowest (2.60\%) was recorded in Sohag Governorate. In Lower Egypt Governorates, Al- Behiera Governorate fields recorded a higher disease incidence and severity than all Governorates, the highest disease incidence was $15.28 \%$ followed by Al-Daqahlia (13.23), Al- Gharbia (12.41), Kafr Al- Shikh (12.70) and Al- Sharqia (12.14) Governorates. The lowest disease incidence recorded in Al- Suiz Governorate (10.27\%), followed by 11.28 , 11.58 and $11.67 \%$ in Al- Qalioubia, Al- Ismailia and Al- Minoufia Governorates respectively. The highest bacterial wilt severity was recorded in $\mathrm{Al}$ - Behiera Governorate, fields (5.70\%), followed by Al- Gharbia (4.60\%), while the lowest bacterial wilt severity was recorded in Al- Suiz Governorate (2.63\%) followed by 3.30, in Al- Qalioubia Governorate. All the collected plants were subjected to PCR to detect the infected samples. The 
expected 288 bp amplicon was detected in bacterial wilt infected samples from above mentioned governorates and diseases percentage and severity were calculated. Intensive study and molecular diagnosis will be needed to supplement the further knowledge.

Open Access: This is an open access article distributed under the terms of the Creative Commons Attribution 4.0 License, which permits unrestricted use, distribution, and reproduction in any medium, provided the original author(s) if the sources are credited.

\section{REFERENCES}

Abd-Alla, M., and Bashandy, S. (2008). Bacterial wilt and spot of tomato caused by Xanthomonas vesicatoria and Ralstonia solanacearum in Egypt. World Journal of Microbiology and Biotechnology, 24(2): 291-292.

Abo-Elyousr, K. and Asran, M. (2009). Antibacterial activity of certain plant extracts against bacterial wilt of tomato. Arch. Phytopathol. Plant Protection, 42: 573- 578.

Aly, M.M. and Abd El-Ghafar, N.Y. (2000). Bacterial wilt of artichoke caused by Ralstonia solanacearum in Egypt. New Disease Report. Plant Pathology, 49: 807.

Aslam, M.N., Mukhtar, T., Hussain, M.A. and Raheel, M. (2017). Assessment of resistance to bacterial wilt incited by Ralstonia solanacearum in tomato germplasm. Journal of Plant Disease Protection, 124: 585-590.

Assefa, M., Dawit, A., Lencho and Hundum, T. (2015). Assessment of wilt intensity and identification of causal fungal and bacterial pathogens on hot pepper (capsicum annuuml.) in Bako Tibbe and Nonno districts of West Shewa Zone, Ethiopia. International Journal of Phytopathology, 4(1): 21-28.

Begum, N., Haque, M.I., Mukhtar, T., Naqvi, S.M. and Wang, J.F. (2012). Status of bacterial wilt caused by Ralstonia solanacearum in Pakistan. Pakistan Journal of Phytopathology, 24(1): 11-20.

Desneux, N., Luna, M.G., Guillemaud, T. and Urbaneja, A. (2011). The invasive South American tomato pinworm, Tuta absoluta, continues to spread in Afro-Eurasia and beyond: the new threat to tomato world production. Journal of Pest Science, 84: 403-408.

Fujiwara, K., Aoyama, C., Takano, M. and Shinohara, M. (2012). Suppression of Ralstonia solanacearum bacterial wilt disease by an organic hydroponic system. J. Gen. Plant Pathology, 78: 217-220.

Gutarra, L., Herrera, J., Fernandez, El., Kreuze, J., and Kreuze, H.L. (2017). Diversity, Pathogenicity, and Current Occurrence of Bacterial Wilt Bacterium Ralstonia solanacearum in Peru. Frontiers in Plant Science, 8: 1221.

Horita, M. and Tsuchiya, K. (2001). Genetic diversity of Japanese strains of Ralstonia solanacearum. Phytopathology, 91: 399407.
Ji, P., Momol M.T.,Olson, S.M., Pradhanang, P.M. and Jones, J.B. (2005). Evolution of thymol as biofunmigant for control of bacterial wilt of tomato under field conditions. Plant Disease, 89: 497-500.

Kago, K.E., Kinyua, M.Z., Okemo, O.P. and Muthini, M.J. (2016). Bacterial wilt, a challenge in solanaceous crops Production at Kenyan highlands and lowlands. World Journal of Research and Review, 3(1): 6-11.

Kim, S.G., Hur, O.S., Ro, N.Y., Ko, H.C., Rhee, J.H., Sung, J.S., Ryu, K.Y., Lee, S.Y. and Baek, H.J. (2016). Evaluation of resistance to Ralstonia solanacearum in tomato genetic resources at seedling stage. Plant Pathology Journal, 32(1): 58-64.

Milling, A., Babujee, L. and Allen, C. (2011). Ralstonia solanacearum Extracellular polysaccharide is a specific elicitor of defense responses in Wilt Resistant Tomato Plants. PLoS ONE, 6(1): 15853. https://doi.org/10.1371/ journal.pone.0015853

Mondal, B., Bhattacharya, I. and Khatua, D.C. (2011). Crop and weed host of Ralstonia solanacearum in West Bengal. Journal of Crop and Weed, 7(2): 195-199.

Opina, N., Tavner, F., Hollway, G., Wang, J.F., Li, T.H., Maghirang, R., Fegan, M., Hayward, A.C., Krishnapillai, V., Hong, W.F., Holloway, B.W. and Timmis, J.N. (1997). A novel method for development of species and strain specific DNA probes and PCR primers for identifying Burkholderia solanacearum (formely Pseudomonas solanacearum). Asia Pacific Molecular Biology and Biotechnology, 5(8): 19-30.

Pastrik, K.H., Elphinstone, J.G. and Pukall, R. (2002). Sequence analysis and detection of Ralstonia solanacearum by multiplex PCR amplification of $16 \mathrm{~s}-23 \mathrm{~s}$ ribosomal intergenic spacer region with internal positive control. European Journal of Plant Pathology, 108: 831- 842.

Seleim, M.A.A., Abo-Elyousr, K.A.M., Abd-El-Moneem, K.M. and Saead, F.A. (2014). First report of bacterial wilt caused by Ralstonia solanacearum biovar 2 race 1 on tomato in Egypt. Plant Pathology Journal, 30(3): 299-303.

Singh, D., Sinha, S., Yadav, D.K., Sharma, J.P., Srivastava, D.K., Lal, H.C., Mondal, K.K. and Jaiswal, R.K. (2010). Characterization of biovar/races of Ralstonia solanacerum the incitant of bacterial wilt in solanaceous crops. New Delhi, India. Indian Phytopathological Society. Indian Phytopathology, 63 (3): 261-265.

Wei, Y., Moreno, C.C., Gongora, T.J., Wang, K., Sang, Y., Duran, R.L. and Macho, A.P. (2018). The Ralstonia solanacearum csp22 peptide, but not flagellin-derived peptides, is perceived by plants from the Solanaceae family. Journal of Plant Biotechnology, 1-14.

Williamson, L., Nakaho, K., Hudelson, B. and Allen, C. (2002). Ralstonia solanacearum race 3, biovar 2 strains isolated from geranium are pathogenic on potato. Plant Disease, 86:987991. 